\title{
Nothing to SeE Here? THE EXTENSION OF PARENT COMPANY LIABILITY IN JAMES HARDIE INDUSTRIES PLC V WHITE
}

\author{
Tom White*
}

\begin{abstract}
In James Hardie Industries plc v White, the New Zealand Court of Appeal considered circumstances where a parent company could be directly liable for defective products produced by its subsidiary while upholding the principles behind separate corporate personality. The Court passed off the case as an unexceptional development in the law, based on an application of ordinary tort law principles and supported by decisions from overseas jurisdictions. However, the Court neglected to consider the underlying policies of the cases it cited, ignored important distinctions between them and the present case and did not inquire into whether they were in fact relevantly applicable. In fact, the Court extended parent company liability for the acts and omissions of its subsidiary far beyond what courts in overseas jurisdictions have held. In doing so, the Court implicitly lifted the corporate veil and failed to acknowledge the impact such a finding of liability would have on the corporate form.
\end{abstract}

\section{INTRODUCTION}

According to a "universal bedrock principle" of company law, a corporation has separate legal personality and limited liability. ${ }^{1}$ The effect of this is that one company usually cannot be held liable for the actions, omissions or debts of any other. ${ }^{2}$ In James Hardie Industries plc $v$ White (JHI) the issue arose as to whether in some circumstances a parent company may be held liable for harm resulting from defective products produced by its subsidiary company. ${ }^{3}$ The New Zealand Court of Appeal (the Court) determined that there were three categories in which a duty of care may be imposed

* Submitted as part of the LLB (Hons) programme at Te Herenga Waka - Victoria University of Wellington. I would like to thank my supervisor, Professor Geoff McLay, for his invaluable advice, guidance and support.

1 Martin Petrin and Barnali Choudhury "Group Company Liability" (2018) 19 EBOR 771 at 772.

2 Adams v Cape Industries plc [1990] Ch 433 (CA) at 536.

3 James Hardie Industries plc v White [2018] NZCA 580, [2019] 2 NZLR 49 [JHI] at [1]. 
upon a parent company for the acts or omissions of its subsidiary so that such liability could arise. ${ }^{4}$ The New Zealand Supreme Court subsequently declined leave to appeal, as a result of which the case will proceed to its substantive hearing. ${ }^{5}$

The Court treated the case as an application of ordinary tort law principles. However, this article concludes that in reality the Court's decision, in extending the tort of negligence to allow a parent company to be held liable for economic loss resulting from the acts or omissions of its subsidiary, was an unwarranted departure from conventional law. It contends that whereas the Court sought to justify its conclusion with reference to overseas authorities, it failed to acknowledge the fundamentally different sets of facts and underlying policy considerations of those cases. The result is that the approach the Court took, and the finding of potential liability it reached, were accordingly misguided.

This introduction forms Part I of the article. Part II sets out the factual background and claims made in the case. The relevant New Zealand legal context behind the case is unique in a number of respects and Part III sets out some of these key considerations. Part IV summarises the decision in $J H I$ and Part V critically analyses the Court's approach, demonstrating the inappropriateness of applying the overseas authorities relied on and highlighting the Court's failure to address the significant implications of parent company liability for the activities of its subsidiary. A preferable solution to the problem, legislative incorporation of the principle of enterprise liability, is briefly posited in Part VI before some concluding comments are made.

\section{THE FACTS AND CLAIMS IN JAMES HARDIE INDUSTRIES PLC v WHITE (JHI)}

The principal issue of $J H I$ concerned when a parent company may be liable for defective products made, marketed and sold by its subsidiary company. ${ }^{6}$ The claimants were past or present owners of approximately 1,132 homes, four commercial buildings and five retirement villages constructed or reclad with exterior cladding products manufactured and supplied by the James Hardie business in New Zealand. The harm alleged was that the products were defective, not watertight and failed to comply with prevailing building standards. ${ }^{7}$

Seven companies within the wider James Hardie commercial group were initially joined as defendants, four operating companies - Studorp Ltd, James Hardie New Zealand Ltd (JHNZ), James Hardie Australia Pty Ltd and James Hardie Research Pty Ltd - and three holding companies - James Hardie Industries Plc (JHI), the ultimate parent of the group, James Hardie New Zealand Holdings

4 At [62] and [65].

5 James Hardie Industries plc v White [2019] NZSC 39.

6 At [1].

7 At [2] and [12]. 
Ltd (JHNZH), the immediate parent of JHNZ, and RCI Holdings Pty Ltd (RCI), the immediate parent of Studorp.

All three holding company defendants sought an early end to the claims against them. JHI, domiciled in Ireland, protested the jurisdiction of the New Zealand courts to determine the proceeding against it, the only issue being whether there was a serious issue to be tried on the merits. ${ }^{8} \mathrm{JHNZH}$ and RCI both sought summary judgment, which required them to show that the claimants' causes of action against them could not succeed, on the basis they did not participate in and were not responsible for the actions of the subsidiary companies. ${ }^{9}$ In the High Court, Peters J dismissed JHNZH and RCI's applications for summary judgment, but upheld JHI's protest to jurisdiction apart from the failure to warn cause of action. ${ }^{10}$ The parent companies appealed from that decision so that the instant issue was whether the three parent companies could properly be joined as defendants to the proceedings.

The claimants made several allegations about the defendants. Firstly, that all the defendants operating and parent companies - had engaged in the business of designing, developing, testing, manufacturing, marketing, distributing and selling the defective product. ${ }^{11}$ Secondly, that the wider James Hardie group had made statements about the nature and quality of the products and had written, published and released technical information concerning the products. ${ }^{12}$ Consequently, the defendants, including the parent companies, were alleged to be liable in negligence and under the Consumer Guarantees Act 1993 (CGA) and Fair Trading Act 1986 (FTA). ${ }^{13}$

The case for the defendants was that to hold the parent companies liable for the activities of their subsidiaries would be to do so in their capacity as shareholder, and as such be inconsistent with the doctrine of the "corporate veil". ${ }^{14}$ It was claimed that use of a corporate group structure did not make a parent company liable for the acts of its subsidiaries and to hold otherwise would undermine the policy objectives facilitated by company law. ${ }^{15}$ Rather, according to the defendants, such liability was limited to two situations only and neither applied here: where the parent company had exercised direct control over the acts of the subsidiary so that it could be said to have assumed responsibility for them, or where the parent company had "superior knowledge" of the risk of harm arising from the acts of

8 White v James Hardie New Zealand [2017] NZHC 2105 at [9]; and JHI, above n 3, at [19].

$9 J H I$, above n 3, at [19]-[20].

10 White, above n 8, at [145].

$11 J H I$, above n 3, at [11].

12 At [11].

13 At [12].

14 At [24].

15 At [24]. 
the subsidiary so that it is safe to infer the subsidiary would rely on the parent to protect against the risk. ${ }^{16}$ In the absence of either of these, it was contended, the parent companies could not be liable.

\section{THE NEW ZEALAND LEGAL CONTEXT}

\section{$A$ The Corporate Form and "Corporate Veil"}

The main legal problem with imposing liability on the parent companies for the acts and omissions of its subsidiaries is that according to a "universal bedrock principle" of company law, a corporation has separate legal personality and limited liability, which together form what is known as the "corporate shield" or "corporate veil". ${ }^{17}$ This was confirmed over a century ago in Salomon $v$ A Salomon \& Co Ltd. ${ }^{18}$ According to this "Salomon principle", a company is separate from its shareholders and other individuals, and shareholders will not be personally liable for the acts or debts of the company. ${ }^{19}$ Thus one company is not responsible for costs, debts or liability incurred by any other company: in order to impose such liability a court must disregard the corporate form to "lift" or "pierce" the "corporate veil" which separates a company from its shareholders. ${ }^{20}$ What the existence of the corporate form means for this case is that the parent companies could not be made to account for the wrongful actions of their subsidiaries, because they are each separate entities responsible for, but only for, themselves.

Unquestionably, limited liability and separate legal personality provide significant economic and societal benefits in encouraging, among other things, significant investment, diversification and innovation, so that it has been said: ${ }^{21}$

Given the importance of the liability-limiting effect of the corporate form for the ... economy, the stakes are high whenever the judiciary sit to decide [its] acceptable limits ...

16 At [23].

17 Petrin and Choudhury, above $\mathrm{n} 1$, at 772.

18 Salomon v A Salomon \& Co Ltd [1897] AC 22 (HL).

19 Salomon, above n 18. See also Nina A Mendelson "A Control-Based Approach to Shareholder Liability for Corporate Torts" (2002) 102 Colum L Rev 1203 at 1211; Petrin and Choudhury, above n 1, at 772; Lord Cooke "A Real Thing: Salomon v A Salomon \& Co Ltd" in The Hamlyn Lectures: Turning Points of the Common Law (Sweet \& Maxwell, London, 1997) 1; Trevor Ivory Ltd v Anderson [1992] 2 NZLR 517 (CA) at 524; and Lee v Lee's Air Farming Ltd [1961] AC 12 (PC).

20 Alan Dignam and Peter B Oh "Disregarding the Salomon Principle: An Empirical Analysis, 1885-2014" (2019) 39 OJLS 16 at $18-19$.

21 At 17. See also David Goddard "Corporate Personality - Limited Recourse and its Limits" (paper presented to Centenary Celebration of Salomon v Salomon Conference, Auckland, 25-26 July 1997); Christian A Witting Liability of Corporate Groups and Networks (Cambridge University Press, Cambridge, 2018); and John Smillie "Tort, Contract and the Limited Liability Company: Reflections on Trevor Ivory Ltd v Anderson" (2008) 14 NZBLQ 96 at 98. 
However, the concern is that the principles of separate personality and limited liability may enable a parent company, "as a shareholder of its subsidiary, to avoid liability for the subsidiary's debts by ... quarantin[ing] actual or potential tort liabilities within an under-capitalised subsidiary". ${ }^{22}$ If the corporate shield is strictly respected, a corporate group may engage in a sort of moral hazard, whereby subsidiaries conduct risky activities without adequate investment on precautions to avoid accidents or otherwise are incentivised to "misinvest" without fear of the group being made liable. ${ }^{23}$

Courts have therefore subsequently considered occasions in which the "veil" of incorporation will be lifted and the corporate form thereby disregarded. However, the process of doing so has been described as "essentially haphazard and irrational", ${ }^{24}$ and a recent empirical analysis found that while "the extent of [the Salomon principle's] influence has ebbed and flowed ... courts seem relatively reluctant to disregard the corporate form" and that "concerns about [its] diminished sanctity ... may be overblown". 25

New Zealand's strong adherence to the Salomon principle is infamously illustrated in Trevor Ivory Ltd $v$ Anderson. ${ }^{26}$ In that case, the director of a one-person company negligently provided advice to the claimants to spray couch grass weed growing around raspberry canes with a herbicide, failing to divulge the need to protect the raspberry plants before spraying, as a result of which the raspberry crop was severely affected. ${ }^{27}$ The company was clearly liable for breach of contract and negligent misstatement; the question at issue was whether the director, Mr Ivory, was personally liable as well. ${ }^{28}$ The Court of Appeal held he was not. Despite the fact Mr Ivory had himself provided the advice which was then followed to the letter, it was considered that in the absence of "something special" he had disattributed his liability to the company. ${ }^{29}$ The justifications given emphasised the importance of these fundamental principles of company law. The Court, led by Cooke P, considered that in forming and trading as the company, Mr Ivory had made it clear the business was being carried on with limited liability and believed that to impose personal liability would erode separate corporate personality and

22 Phillip Lipton "The Mythology of Salomon's Case and the Law Dealing with the Tort Liabilities of Corporate Groups: An Historical Perspective" (2014) 40 Mon LR 452 at 454.

23 Henry Hansmann and Reinier Kraakman "Toward Unlimited Shareholder Liability for Corporate Torts" (1991) 100 Yale LJ 1879 at 1882-1883.

24 LCB Gower and P Davies Principles of Modern Company Law (6th ed, Sweet \& Maxwell, London, 1997) at 138, as quoted in Dignam and Oh, above n 20, at 18.

25 Dignam and Oh, above n 20, at 19 and 46.

26 Trevor Ivory, above n 19.

27 At 519. See Smillie, above n 21, at 96-97.

28 Trevor Ivory, above n 19, at 519.

29 At 524; Neil Campbell and John Armour "Demystifying the Civil Liability of Corporate Agents" (2003) 62 CLJ 290 at 292; and Cooke, above n 19, at 18. 
undermine Mr Ivory's object in doing so. ${ }^{30}$ This conclusion has caused some confusion and has been heavily criticised, one commentator describing the reasoning as "from another planet". 31

The position now is that Trevor Ivory can apply only to cases where a director has "assumed a responsibility to the plaintiff for the due performance of their roles". ${ }^{32}$ Nevertheless, this case exemplifies the strong commitment of New Zealand courts to the principles of separate personality and limited liability - so strong that in 1997 the same Lord Cooke, as he was by then, felt able to say extrajudicially that "the Salomon principle may wax rather than wane". ${ }^{33}$

\section{B Tort Liability for Economic Loss in New Zealand}

The second relevant contextual element is that damage usually falls into one of three types: personal injury, damage to property or (pure) economic loss. Donoghue $v$ Stevenson provides recovery for negligently harming one's neighbour. ${ }^{34}$ However, it "stands only for the proposition that we owe one another duties not carelessly to damage the person or the tangible property of others". ${ }^{35}$ Pure economic loss, on the other hand, is "a financial loss which is not causally consequent upon physical injury to the plaintiff's own person or property." ${ }^{36}$ Ostensibly the claimants in the present case may have suffered damage to property as a result of the defective exterior cladding product. However, really such damage is economic loss: the damage is not the negligent destruction of an owner's house but rather the decrease in the value of the house as a result of faulty products or alternatively the cost of putting the situation right. ${ }^{37}$

30 Trevor Ivory, above n 19, at 524. See also Smillie, above n 21, at 97

31 Peter Watts "Trevor Ivory v Anderson: reasoning from outer space" [2007] NZLJ 25 at 26. See also Susan Watson and Chris Noonan "The corporate shield: What happens to directors when companies fail?" (2005) 7 UABR 27 at 32; and Grant Brittain "A Builder's Duty of Care - When Should it Apply to the Directors and Employees of Companies Involved in the Creation of Defective Buildings?" (LLM Thesis, Victoria University of Wellington, 2017) at 66.

32 Peter Watts "Managerial and worker liability for shortcomings in the building of leaky homes - an antediluvian perspective" in Steve Alexander and others The Leaky Buildings Crisis: Understanding the Issues (Thomson Reuters, Wellington, 2011) 139 at 152; and Body Corporate 202254 v Taylor [2008] NZCA 317, [2009] 2 NZLR 17 at [33]-[34].

33 Cooke, above n 19, at 18

34 Donoghue v Stevenson [1932] AC 562 (HL).

35 Watts "Managerial and worker liability for shortcomings in the building of leaky homes", above n 32, at 140141.

36 Bruce Feldthusen Economic Negligence: The Recovery of Pure Economic Loss (5th ed, Thomson Carswell, Ontario, 2008) at 1.

37 Debbie Ong Siew Ling "Defects in Property Causing Pure Economic Loss: Management Corp Strata Title Plan No 1272 v Ocean Front Pte Ltd (Ssangyong Engineering \& Construction Co Ltd \& Ors, third parties)" [1995] Sing JLS 256 at 259; and Stephen Todd "Policy Issues in Defective Property Cases" in Jason Nyers, 
It can be difficult to distinguish economic loss from property damage, but the distinction is important because recovery in tort for pure economic loss damage is controversial. ${ }^{38}$ Indeed, in England, tort recovery for economic loss is not allowed. ${ }^{39}$ Following some confusion resulting from Anns v Merton London Borough Council, where inadequate building foundations were initially described as property damage, ${ }^{40}$ the Court in Murphy v Brentwood District Council subsequently identified such damage as economic loss and held it was not recoverable in tort. ${ }^{41}$

In New Zealand, the courts have found liability in an inconsistent and confusing manner for loss of this kind. ${ }^{42}$ In 1976, the Court of Appeal in Bowen v Paramount Builders (Hamilton) Ltd, in applying Donoghue $v$ Stevenson to a case it considered involved injury to property, held that the principal company of the business that built the house was directly liable for its defective product, rather than vicariously liable for the poor building work of its employees. ${ }^{43}$ A decade later, a "trilogy" of cases dealing with failures to advise about flooding (Brown v Heathcote County Council), ${ }^{44}$ to warn against the risk from faulty weatherboard (Stieller v Porirua City Council) ${ }^{45}$ and to notify neighbours of plans which might affect them (Craig v East Coast Bays City Council) ${ }^{46}$ continued this trend of increased liability in negligence. ${ }^{47}$ Lastly, in 1994 the Privy Council in Invercargill City Council v Hamlin imposed liability on the Council for defects caused by its building inspector's negligence, in the process distinguishing Murphy on the basis of circumstances special to New Zealand. ${ }^{48}$ However, more recent cases have affirmed that the allowances made for recovery in those cases represent an

Erika Chamberlain and Stephen GA Pitel (eds) Emerging Issues in Tort Law (Hart Publishing, Oxford, 2007) 199 at 200.

38 Feldthusen, above n 36, at 174; and Geoff McLay "Legal doctrine, the leaky homes crisis and the limits of judicial law-making" in Steve Alexander and others The Leaky Buildings Crisis: Understanding the Issues (Thomson Reuters, Wellington, 2011) 3 at 3.

39 See Ong Siew Ling, above n 37, at 259.

40 Anns v Merton London Borough Council [1978] AC 728 (HL).

41 Murphy v Brentwood District Council [1991] 1 AC 398 (HL) at 468.

42 See generally McLay, above $\mathrm{n} 38$.

43 Bowen v Paramount Builders (Hamilton) Ltd [1977] 1 NZLR 394 (CA) at 406; and Watts "Managerial and worker liability for shortcomings in the building of leaky homes", above $\mathrm{n} 32$, at 139.

44 Brown v Heathcote County Council [1986] 1 NZLR 76 (CA).

45 Stieller v Porirua City Council [1986] 1 NZLR 84 (CA).

46 Craig v East Coast Bays City Council [1986] 1 NZLR 99 (CA). See McLay, above n 38, at 7-9.

47 See McLay, above n 38, at 7-9.

48 Invercargill City Council v Hamlin [1994] 1 NZLR 513 (CA) at 524 per Cooke P, at 529 per Casey J and at 546 per McKay J. 
exception to the general rule that damages for pure economic loss are generally irrecoverable in negligence. 49

The justification for recovery in tort for economic loss is not as strong as those for personal injury. ${ }^{50}$ Indeed, the best reasons given in Hamlin for economic loss liability were that to decide otherwise would have "significant community implications" and "call for a major attitudinal shift". ${ }^{51}$ However, economic loss and personal injury are different in kind as well as degree: there is a "qualitative difference" between injury to a human being and injury to economic expectations alone. ${ }^{52}$ Moreover, with economic loss there is not a loss of a "thing" per se, but rather a transfer of wealth. This in turn is mitigated by the ability to efficiently enter into contractual allocations of loss with a perpetrator through insurance or breach of warranty. ${ }^{53}$ Rather, as has been commented elsewhere, to impose tortious liability on parties for economic loss arising out of defective product is to make a warranty function out of tort and regulators out of judges who decide which industries and people they will regulate and protect, a role probably best left to Parliament. ${ }^{54}$ Nevertheless, the important point presently is that it remains the position in New Zealand that the creation of defective houses is rightly or wrongly a matter of tort liability.

\section{Existing Statutory Regimes for Recovery}

The final preliminary point concerns the existence in New Zealand of relevant statutory regimes and their potential use as appropriate routes of recovery for the claims which arose in JHI. Where statutory provision for recovery exists it is preferable to apply the statutory scheme rather than developing and expanding common law doctrines, inasmuch for the practical reasons of the increased certainty and clarity statute provides as constitutional reasons of parliamentary supremacy and

49 Te Mata Properties Ltd v Hastings District Council [2008] NZCA 446, [2009] 1 NZLR 460 at [62]; and Attorney-General v Carter [2003] 2 NZLR 160 (CA) at [34]. See McLay, above n 38; and Sladjana Kovacevic "Litigating a 'Natural Disaster': The inadequacies of the tort of negligence in response to the leaky building crisis" (LLB (Hons) Dissertation, Victoria University of Wellington, 2010) at 21.

50 See generally Feldthusen, above n 36

51 Hamlin, above n 48, at 528 .

52 Feldthusen, above n 36, at 9.

53 Bruce Feldthusen "Liability for Pure Economic Loss: Yes, But Why?" (1999) 28 UWA Law Review 84 at 87; and Todd "Leaky buildings: limitation issues and successive owners", above n 53, at 124-125.

54 Murphy, above n 41, at 441; Mt Albert Grammar School Board of Trustees v Auckland City Council HC Auckland CIV-2007-404-4090, 25 June 2009 at [70]; and Watts "Managerial and worker liability for shortcomings in the building of leaky homes", above n 32, at 139. 
democratic mandate. ${ }^{55}$ Indeed, recovery under tort where statutory a remedy is available would appear unnecessary and has been denied in the past. ${ }^{56}$

\section{Fair Trading Act 1986}

The FTA contains in essence a statutory, no-fault, strict liability tort which prohibits misleading or deceptive conduct in trade, as well as more specifically a proscription against false or misleading representations as to the characteristics of goods ${ }^{57}$ For this purpose, a corporation is deemed to have engaged in any conduct engaged in by any person acting within their authority or by agreement on its behalf. ${ }^{58}$ Once such conduct is found, a court may make broad orders, including damages for the amount of the loss or damage. ${ }^{59}$

\section{Consumer Guarantees Act 1993}

Under the CGA, a "consumer" has a right of redress against a "manufacturer" of goods for any reduction in the value of the goods or loss or damage reasonably foreseeable from failure of the guarantee that the goods be of acceptable quality. ${ }^{60}$ The right is not restricted to the original consumer but continues to any subsequent purchaser. ${ }^{61}$ This would therefore appear to provide for recovery for the present claimants. However, there are two main issues with applying the CGA to the present case. First, "goods" is defined broadly and includes goods "attached to, or incorporated in, any real or personal property", yet does not include "a whole building, or part of a whole building, attached to land". ${ }^{62}$ Second, the CGA precludes recovery where the failure is due to any person other than the manufacturer, meaning that it would not apply if a parent could show the failure was due to the subsidiary. ${ }^{63}$ These are issues which may constitute insurmountable obstacles in relation to the present case in the absence of legislative amendment.

\section{Companies Act 1993}

The Companies Act 1993 also potentially allows a claimant to recover from a parent company provided the subsidiary company goes into liquidation. Section 271 was introduced following

55 See for example Anthony Mason "The interaction of statute law and common law" (2015) 27 JOB 87.

56 NZ Food Group (1992) Ltd v Amcor Trading (NZ) Ltd (1999) 9 TCLR 184 (HC) at 198-199 and 203.

57 Sections 9 and $13(\mathrm{a})$.

58 Section $45(2)$.

59 Section 43(3)(f).

60 Sections 25 and 27(1)

61 Section 27(1); and Todd "Leaky buildings: limitation issues and successive owners", above n 53, at 127.

62 Section 2.

63 Section 26(a)(i). 
concerns about the potential for a parent company to abandon its subsidiary upon incurring a liability. ${ }^{64}$ It provides a mechanism for a court, if satisfied it is just and equitable to do so, to order a "related" company to pay the whole or part of any or all of the claims made in the liquidation. ${ }^{65}$ "Just and equitable" is determined broadly and depends on consideration of factors such as the related company's management, conduct towards creditors, responsibility and any "such other matters as the court thinks fit". ${ }^{66}$ The mechanism applies only to the liabilities of a company in liquidation and so strictly would not be useful here. Nevertheless, it demonstrates at least some willingness of the legislature to make "inroads" on the Salomon principle and removes some of the concerns about not being able to sue the relevant parent company itself. ${ }^{67}$

The decision in the present case must, therefore, be considered in the light of these existing statutory regimes.

\section{THE DECISION IN JHI}

\section{A Principles}

This case was the first considered decision of the New Zealand Court of Appeal on the imposition of a duty of care upon a parent company for the acts of its subsidiaries. ${ }^{68}$ In seeking to resolve whether the parent companies could be so liable, the Court looked into three lines of authority. ${ }^{69}$ The first concerned the principle of separate legal personality for corporate entities and the second the circumstances in which a novel duty of care will be imposed. ${ }^{70}$ The third, said to link the first two together, involved an examination of decisions from overseas jurisdictions as to the circumstances in which a parent company may owe a duty of care to those affected by the actions and omissions of its subsidiary. ${ }^{71}$

The Court emphasised separate corporate personality as "central". ${ }^{72}$ This meant a company is therefore a legal person with rights and duties that can be enjoyed or borne by a natural legal person

64 Ian Hannay Macarthur Final Report of the Special Committee to Review the Companies Act (Ministry of Economic Development, March 1973) [Macarthur Report] at [405]. See also Goddard, above n 21, at 45.

65 Section 271.

66 Section 272(1).

67 See Goddard, above n 21, at 50.

$68 J H I$, above n 3, at [39].

69 At [27].

70 At [27].

71 At [27].

72 At [28]. 
and that it exists separately from the legal personalities of its shareholders. ${ }^{73}$ Accordingly, there is no duty of care on a parent company merely because of its ability through its shareholding to control operations: something more than mere ownership and the control which comes with that is required. ${ }^{74}$ Concordantly, however, because a parent company is as capable of assuming a duty of care as any other company or person, there is nothing about its position that will shield it from a duty of care where it is brought into such proximity as to justify imposing one. ${ }^{75}$ The Court maintained that the principles they outlined for the potential liability of a parent company were not inconsistent with the "concepts underpinning separate legal personality" in New Zealand company law, but in fact "depend[ed] upon" them. ${ }^{76}$

The Court recognised that such a finding of potential parent company liability would be "novel" - one not previously imposed in earlier case law - since it concerned "a largely untouched area of law in this jurisdiction". ${ }^{77}$ In so acknowledging, the Court recognised that a positive finding of potential liability would be a new development for the law of New Zealand: a departure from the existing state of law. One might expect, as a consequence, additional explanation justifying such a course.

For the circumstances in which a parent company may owe a duty of care for the acts of its subsidiaries, the Court looked to authorities from other jurisdictions. The applicability and relevance of those authorities will be examined below. Nevertheless, from its analysis of those decisions the Court outlined three potential categories of liability: ${ }^{78}$

(a) where the parent takes over the running of the relevant part of the business of the subsidiary;

(b) where the parent has superior knowledge of the relevant aspect of the business of the subsidiary, the subsidiary relied upon that knowledge, and the parent knew or ought to have foreseen the alleged deficiency in process or product; and

(c) more generally where the parent takes responsibility (irrespective of superior knowledge or skill) for the policy or advice which is linked to the wrongful act or omission.

73 At [28]; and Peter Watts, Neil Campbell and Christopher Hare Company Law in New Zealand (2nd ed, LexisNexis, Wellington, 2016) at 23.

$74 J H I$, above n 3, at [63] and [33].

75 At [63].

76 At [64].

77 At [34]-[35].

78 At [65] (emphasis added, footnotes omitted). 


\section{B Application and Result}

The Court analysed affidavit and documentary evidence which in totality created "admittedly only ... a sketchy picture."79 The defendants' affidavit evidence as outlined portrayed JHI as a "passive holding company" with three staff and "no role in the operations of its subsidiaries". ${ }^{80}$ However, the Court emphasised that the defendants were in a position to provide detail as to how the wider James Hardie group coordinates and chose not to do so. ${ }^{81}$ The main evidence for the claimants came from affidavits from a former employee as well as an annual report for JHI and "downloads" from the James Hardie New Zealand and Australian websites. ${ }^{82}$ The Court considered these presented an image of the companies as a "single entity" group which used shared resources for research and enjoyed delegated authority to pursue a single business strategy. ${ }^{83}$ Great weight was placed on a JHI-based executive team which was said to have "direct involvement in the manufacturing operations in New Zealand" and to suggest on their part "superior knowledge about the technical specifications of the products, and some level of control over the local operations". 84

The Court considered that the evidence as presented suggested that the group coordinated according to a "top down approach ... and a pooling of technical knowledge and research". ${ }^{85}$ The Court was satisfied that this evidential narrative was sufficient to raise a serious issue that the conduct of JHI brought it within the categories for potential liability they had outlined (running; superior knowledge; or responsibility). ${ }^{86}$ Accordingly, in the substantive hearing of these proceedings JHI may find itself the subject of a duty of care imposed upon it in connection with the activities of its subsidiaries. $^{87}$

Prior to this case, it was thought that a parent company would not be liable for wrongful acts of its subsidiaries, on account of its separate legal identity. The result of the case is that a parent company may indeed be liable if its conduct falls within one of the categories outlined above, the most radical departure being the second category (superior knowledge).

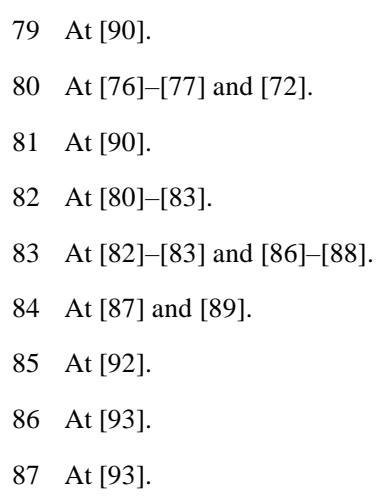




\section{ANALYSIS: THE EXTENSION OF TORT LIABILITY TO A PARENT COMPANY FOR ECONOMIC LOSS CAUSED BY DEFECTIVE PRODUCTS PRODUCED BY ITS SUBSIDIARY}

In $J H I$, the Court determined that there were three categories wherein a parent company could be directly liable for defective products produced by its subsidiary while upholding the principles behind separate corporate personality. The Court passed off the case as an unexceptional development in the law, based on an application of ordinary tort law principles and supported by decisions from overseas jurisdictions. However, the Court neglected to consider the underlying policies of the cases cited, ignored important distinctions between them and the present case and did not inquire into whether they were in fact relevantly applicable. In fact, the Court extended liability far beyond what courts in overseas jurisdictions have held. In doing so, the Court implicitly lifted the corporate veil and failed to acknowledge the impact such a finding of liability would have on the corporate form.

\section{A Application of Tort Cases}

As a preliminary consideration, the Court failed to recognise the inappropriateness of applying tort principles to address the present issue, a situation which involved contractual arrangements between the parties.

As highlighted earlier, following Murphy the English courts have returned to a position where economic loss for defective structures is irrecoverable in tort. However, New Zealand courts continue to treat the creation of defective houses as a tort issue. ${ }^{88} \mathrm{JHI}$ is therefore mainly framed in negligence, whereby the parent company owed a duty of care to third parties it could reasonably foresee would be affected by the acts and omissions of its subsidiary, which it breached by failing to ensure that its subsidiary did not harm those third parties. Really, however, the underlying problem was not that the subsidiary harmed the claimants in negligently manufacturing and supplying defective cladding products, but rather that the subsidiary and claimants entered into contracts for the purchase and provision of cladding products of good, watertight and standard-compliant quality and that the products did not meet that quality. ${ }^{89}$ The real issue, therefore, was one of failure to perform terms in the contract, not failure to take reasonable care not to harm third parties.

In the presence of a contractual arrangement where parties have voluntarily allocated and assumed risks, it is more appropriate to deal with the case in terms of the obligations accepted by the parties in their contract, rather than those imposed by the Court in tort. ${ }^{90}$ Despite this, the Court unquestioningly

88 Bowen, above n 43; and Hamlin, above n 48.

89 Watts "Managerial and worker liability for shortcomings in the building of leaky homes", above n 32, at 140.

90 See the dissent of La Forest J in London Drugs Ltd v Kuehne \& Nagel International Ltd [1992] 3 SCR 299. In his Honour's opinion (at 388), an employee was liable to a plaintiff for their independent torts, but if the tort is related to the performance of a contract, liability must be determined with the contractual context in mind. 
looked to apply "tort" case principles from overseas jurisdictions without inquiring whether they were in fact directly relevant and applicable in light of the contractual arrangements, and instead extended potential liability in tort to an indeterminate extent, with potentially far-ranging implications.

\section{B Consistency with Overseas Developments}

Notwithstanding the above, the cases the Court cited were themselves not relevantly applicable to the present situation. The present case concerned economic loss caused by defective products, whereas the authorities cited by the Court in support of its decision describe situations of personal injury, harm to property and amenity of life, environmental pollution and human rights abuses. Accordingly, they are not good authorities for the imposition of parent company liability in the three categories outlined and the Court was accordingly wrong to use the rules from the cases without acknowledging this or providing further justification for doing so.

\section{Australia}

The first authorities considered were two decisions of the New South Wales Court of Appeal apparently "difficult to reconcile in light of the factual findings at first instance": CSR Ltd v Wren and James Hardie \& Co Pty Ltd v Hall. ${ }^{11}$ In CSR an employee of Asbestos Products Pty Ltd contracted mesothelioma in the course of his employment half a century earlier. ${ }^{92}$ The Court found that CSR, the parent company, had, in placing its own staff in management roles in the subsidiary, taken such direction and control of its subsidiary that it had a duty of care to the employee to provide, establish and maintain a safe system of work. ${ }^{93}$

In a contrasting conclusion, the Court in Hall considered that the factual findings at first instance were not sufficient to warrant such a duty of care in the absence of any evidence that the subsidiary was a mere façade, whereby those responsible for workplace safety at the subsidiary premises were really employees of the parent company. ${ }^{94}$ To have made the defendant parent company liable in the absence of any such evidence of direct involvement, control or influence, the Court said, would have been to implicitly lift the corporate veil and ignore the companies' separate legal identities. ${ }^{95}$

The Court in JHI directly imported the rule from CSR as one of the categories for potential liability. ${ }^{96}$ However, this should have been accompanied by some justification, since it is distinct from

$91 J H I$, above n 3, at [45]; CSR Ltd v Wren (1997) 44 NSWLR 463 (NSWCA); and James Hardie Co Pty Ltd v Hall (1998) 43 NSWLR 554 (NSWCA).

$92 C S R$, above n 91, at 467.

93 At 465 and 484.

94 Hall, above n 91, at 581.

95 At 581 and 584.

$96 J H I$, above n 3, at [65(a)]. 
$J H I$ at a number of levels. First, the level of involvement of the parent company in $J H I$ appears to fall closer to that in Hall than in CSR, which concerned "a very different factual matrix [from Hall] ... [where] the employees of CSR (the parent company) ... controlled the day-to-day operations of the subsidiary". ${ }^{97}$ Additionally, the claimants in those cases were employees of the subsidiary company as opposed to third party customers and the cases concerned negligent workplace health and safety resulting in personal injury rather than economic loss resulting from defective products. To have imported the rule from $C S R$ without further justification was thus flawed.

\section{England}

Appropriately, the Court in $J H I$ referred to the first decision to establish parent company liability for negligence, Chandler v Cape plc, where it was accepted that "in appropriate circumstances the law may impose on a parent company responsibility for the health and safety of its subsidiary's employees". ${ }^{98}$ In that case, the parent company was found to have assumed a duty of care to the claimant employee "[g]iven [its] state of knowledge about [the workplace], and its superior knowledge about the nature and management of asbestos risks" and breached that duty by failing to create a safe system of work, causing the plaintiff to contract asbestosis half a century later. ${ }^{99}$ A similar issue arose in Thompson $v$ The Renwick Group plc, where the claimant had been incapacitated by diffuse pleural thickening caused by exposure to asbestos dust. ${ }^{100}$ Although the parent company had appointed to the subsidiary a director with responsibility for health and safety matters, the facts were "far removed" from Chandler and fell "far short" of what was required for the assumption of a duty of care. ${ }^{101}$ The Court in JHI, however, found that Thompson supported the rule in Chandler, albeit not satisfied on the facts. ${ }^{102}$

Although both cases were relied on by the Court in $J H I$ as support for its categories of liability, neither is in fact directly relevant: both cases deal with the health and safety of workplace employees. This difference is more than cosmetic: as touched on above, the rationale for liability for personal injury is far stronger than for economic loss. Neither can the principles be extracted more broadly, not without further justification.

97 Hall, above n 91, at 583.

98 Chandler v Cape plc [2012] EWCA Civ 525, [2012] 1 WLR 3111 at [80].

99 At [78].

100 Thompson v The Renwick Group plc [2014] EWCA Civ 635 at [1].

101 At [24], [29] and [39].

102 At [49]-[50]. 
A trio of cases have recently been working their way through the English courts: Lungowe $v$ Vedanta Resources plc, Okpabi v Royal Dutch Shell plc and AAA v Unilever plc. ${ }^{103}$ The JHI Court attempted to extract applicable principles for liability from these cases as well. However, because the facts and underlying policy concerns of these cases are far removed from the present, the principles from them are again of limited utility.

In Lungowe, Zambian citizens sued a United Kingdom parent company for personal injury, damage to property and loss of income, amenity and enjoyment of land caused by pollution and environmental damage resulting from discharges from a copper mine owned and operated by the parent's subsidiary. ${ }^{104}$ Although the claims alleged economic loss in the form of loss of income, the English Court of Appeal in considering Chandler and Thompson stated a duty may be owed where the parent company: ${ }^{105}$

(a) has taken direct responsibility for devising a material health and safety policy the adequacy of which is the subject of the claim, or (b) controls the operations which give rise to the claim.

In other words, the categories for potential liability relate to health and safety and therefore damage in the form of personal injury, not the economic loss which was also alleged. Further, the Court in Lungowe emphasised that to be liable the parent must be "well placed, because of its knowledge and expertise[,] to protect the employees of the subsidiary". ${ }^{106}$ The JHI Court noted the allowance made in Lungowe for both parent and subsidiary to owe a duty of care to those affected by decisions made by them jointly. ${ }^{107}$ However, the evidence in $J H I$ was that decisions were never made jointly, and as such this is unhelpful to the imposition of a duty. Some support for the finding in JHI may be found in that the duty may be owed "not only to employees of the subsidiary but to those affected by the operations of the subsidiary". ${ }^{108}$ The Court in JHI does not include this in its final categorisation of liability, however.

The second case, Okpabi, concerned "serious, and ongoing, pollution and environmental damage caused by leaks of oil from pipelines" around the Niger delta. ${ }^{109}$ The claimants alleged that the United Kingdom parent company owed them a duty of care either because it controlled the subsidiary's operations or assumed direct responsibility for its practices. The decision in the case suggests the level

103 Lungowe v Vedanta Resources plc [2017] EWCA Civ 1528, [2018] 1 WLR 3575; Okpabiv Royal Dutch Shell plc [2018] EWCA Civ 191; and AAA v Unilever plc [2018] EWCA Civ 1532.

104 Lungowe, above n 103, at [1]-[2].

105 At [83].

106 At [83].

107 At [83]; and $J H I$, above n 3, at [53].

108 Lungowe, above n 103, at [83].

109 Okpabi, above n 103, at [1]. 
of control the parent company must exercise before a duty of care will be imposed is considerable: concern about ensuring proper systems were put in place to reduce oil losses and environmental damage and the establishment of an overall system to ensure best uniform practices did not meet the threshold for control justifying liability. ${ }^{110}$ Indeed, the existence of a corporate structure "itself tends to militate against the requisite proximity [for a duty of care]". ${ }^{11}$ Although Sales LJ in dissent did consider that "a mechanism for the projection of real practical executive control" would be sufficient to find an assumption of responsibility and therefore liability, the high evidential threshold may be contrasted with the Court in $J H I$ allowing the possibility for liability based on seemingly scant evidence of direction and coordination. ${ }^{112}$

Finally, $A A A$ involved serious targeted intertribal violence in Kenya, the claimants alleging their employer and its parent company owed a duty of care to protect them from this violence. ${ }^{113}$ The Court of Appeal considered that cases where a parent company had taken action which justifies the imposition of a duty of care would usually be of two types: where they had in substance taken over the management of the relevant activity or given relevant advice to the subsidiary as to how to manage a particular risk. ${ }^{114}$ Neither had occurred there. ${ }^{115}$ Of note, however, the $A A A$ Court gave what the Court in $J H I$ called a "helpful summary" of the relevant principles, in particular that: ${ }^{116}$

A parent company will only be found to be subject to a duty of care in relation to an activity of its subsidiary [vis-à-vis persons affected by those activities] if ordinary, general principles of the law of tort

$\ldots$ are satisfied in the particular case.

Although $A A A$ concerned personal injury, the principles were, unlike in the other cases, framed generally and may have wider application. Indeed, they provide some support for parent company liability in recognising a parent may have "greater scope to intervene in the affairs of its subsidiary than another third party might have". ${ }^{117}$ However, the case gave the following as the two usual cases where this will occur: ${ }^{118}$

110 At [127] per Simon LJ.

111 At [196] per Sir Geoffrey Vos C.

112 At [161] per Sales LJ (dissenting); and JHI, above n 3, at [90].

$113 A A A$, above n 103 , at [2].

114 At [37].

115 At [38]-[40].

116 At [36], as quoted in $J H I$, above n 3, at [59].

117 AAA, above n 103, at [37].

118 At [37]. 
(i) where the parent has in substance taken over the management of the relevant activity of the subsidiary in place of (or jointly with ...) the subsidiary's own management; or (ii) where the parent has given relevant advice to the subsidiary about how it should manage a particular risk.

The United Kingdom Supreme Court has subsequently endorsed these passages in Lungowe, stating: ${ }^{119}$

Everything depends on the extent to which ... the parent availed itself of the opportunity to take over,

intervene in, control, supervise or advise the management of the relevant operations ... of the subsidiary.

The two quoted passages above align with, and provide for, the first (running) and third (responsibility) categories of potential liability outlined in JHI. The second category identified (superior knowledge), however, is noticeably absent from both. The relevance of this is covered in the next section.

\section{Canada}

In support that the imposition of a duty "does not entail the piercing of the corporate veil", ${ }^{120}$ the Court in JHI referred to Choc v Hudbay Minerals Inc, where a claim was allowed based on the parent company's "on-the-ground" control as opposed to its shareholding control. ${ }^{121}$ Again, however, and as explicitly indicated by the Court, that case concerned claims of human rights abuses committed by security personnel working for the subsidiary, including assault and sexual assault. ${ }^{122}$ Accordingly, any relevance of "on-the-ground" control in that case was negligible to determining when a parent company could be liable for economic loss resulting from the production of defective products.

\section{Conclusions on overseas authorities}

To conclude, the main problem with the use of the authorities cited is that the Court in JHI failed to recognise that the cases were dealing with different underlying policies and addressing different questions. While broadly each of the cases relates to potential parent company liability to individuals affected by acts of their subsidiaries, they are all far removed from the situation in JHI. CSR, Hall, Chandler and Thompson all related to ensuring the health and safety of employees of the subsidiary company in respect of asbestos exposure, the duty of care in question being to ensure a safe workplace. Lungowe and Okpabi concerned pollution and environmental damage as well as, in the former, personal injury, damage to property and loss of income, amenity and land. $A A A$ and Choc concerned harmful personal injury in relation to, respectively, intertribal violence and assault. The factual matrices of those cases are thus far removed from the facts of $J H I$ and consequently are weak

119 Lungowe v Vedanta Resources plc [2019] UKSC 20, [2019] 2 WLR 1051 at [49].

$120 \mathrm{JHI}$, above n 3, at [60].

121 Choc v Hudbay Minerals Inc 2013 ONSC 1414, (2013) 116 OR (3d) 674 at [67].

122 At [4]-[7]; and JHI, above n 3, at [61]. 
authorities for principles governing the imposition of a duty of care in relation to economic loss caused by defective products. The only instance of economic loss in these cases is the loss of income alleged in Lungowe, but the Court in that case addressed itself only to the health and safety considerations. The greatest assistance to the Court's finding in $J H I$ is in fact to be found in $A A A$, a case which did not concern economic loss but did lay out a summary of general principles for parent company liability. ${ }^{123}$ However, even that summary did not support fully the $J H I$ categories of liability, in particular the second. The impacts of potential liability based on that second category are explored now.

\section{A New Category of Liability: Superior Knowledge}

The first (running) and third (responsibility) categories of the imposition of a duty of care arise from orthodox tort principles of control, or an assumption of responsibility so that a parent company may fairly be said to have assumed a duty of care. However, the second (superior knowledge) category of parent company liability represents a departure from ordinary tort principles and goes far beyond what courts in other jurisdictions have decided. Under the second category, a duty may exist: ${ }^{124}$

(b) where the parent has superior knowledge of the relevant aspect of the business of the subsidiary, the subsidiary relied upon that knowledge, and the parent knew or ought to have foreseen the alleged deficiency in process or product; ...

Whereas authority was provided for the first and third categories, no such authority was given for the second. The likely source, however, is Chandler, which gave the following as an example of when such a duty may arise: ${ }^{125}$

where ... (1) the businesses of the parent and subsidiary are in a relevant respect the same; (2) the parent has, or ought to have, superior knowledge on some relevant aspect of health and safety in the particular industry; (3) the subsidiary's system of work is unsafe as the parent company knew, or ought to have known; and (4) the parent knew or ought to have foreseen that the subsidiary or its employees would rely on its using that superior knowledge for the employees' protection.

The $J H I$ formulation extends the duty to knowledge of a relevant aspect of the business and of deficiency in process or product and removes the condition of reliance on the superior knowledge for the employees' protection. The material differences between the two formulations as italicised are important: they entail completely different justifications. There is no problem with a court extending the scope of liability; subsequent cases have observed the passage in Chandler is an example, not an

$123 A A A$, above n 103, at [36].

$124 \mathrm{JHI}$, above n 3, at [65] (emphasis added).

125 Chandler, above n 98, at [80] (emphasis added). 
exhaustive list. ${ }^{126}$ Rather, the issue arises in failing to explicitly recognise the effects resulting from differences between liability for superior knowledge in relation to the safety of a workplace and health of employees and in relation to economic loss to unknown third parties resulting from defective products. The Court failed to acknowledge that this was a departure from the current law and that liability under the second category could be unduly expansive and strict.

Whereas the Chandler formulation describes a situation where it seems the parent company has an implied obligation to act, it is more difficult to rationalise that a party would have really assumed a duty of care to third parties under the $J H I$ formulation where its responsibility stems from mere knowledge concerning another party's manufactured products. To impose liability in such a case would be to hold a parent company to an unreasonable standard, requiring it to act and intervene to "save" third parties from processes or products potentially entirely unrelated to its own operations. To require such intervening action is a significant incursion into separate legal personality, notwithstanding the Court's contention otherwise.

The theoretical justifications for liability also tell against liability for mere knowledge. Ensuring a parent company takes necessary precautions when it is aware that the health and safety of its employees are at risk would appear to have stronger moral underpinnings than rectifying defective products. Since "a human being is not a thing" it may make sense therefore to hold companies to a higher level of accountability in ensuring the health and safety of persons. ${ }^{127}$ However, the same level is not necessarily appropriate for ensuring the quality of fundamentally material goods such as building materials, however valuable and integral they may be.

Such a low threshold would also have the potential to expose defendant parent companies to indeterminate liability. Involuntary creditors such as employees will be a necessarily limited class known or discoverable to a parent company, whereas those affected by defective products may be unknown and inaccessible to a parent company which is removed from the sale and delivery aspect of its subsidiary's business. A parent company aware of a certain number of workplace employees may practically and realistically factor the cost of workplace safety into its operations; liability to an unknown number of third party customers would be indeterminate and potentially commercially impossible. Such liability to voluntary creditors would be better dealt with through contractual rights in warranties and the ability to allocate risk before dealing.

\section{Implications of Expanded Liability}

In applying, and in fact extending, the potential circumstances for the imposition of a duty of care on a parent company, the Court in $\mathrm{JHI}$ failed to acknowledge important implications such increased and uncertain liability may have.

126 Thompson, above n 100, at [33].

127 Feldthusen, above n 36, at 9. 


\section{A roadmap to excessive liability}

The effect of the $J H I$ case for group corporate structures appears to be that parent companies are always going to be joined to proceedings against a subsidiary company, no matter the level of real involvement; a parent will typically have deeper pockets and therefore will usually be more attractive to claimants to sue. This case has not only made possible the ability to do so, but has in fact set out a broad framework for a claimant to fit their case within. This may result in excessive liability as it will apply even to geographically and relationally dislocated parent companies which have not assumed a duty by their control or assumption of responsibility, but which perhaps fit under the second category in particular.

Liability for acts of its subsidiary may incentivise a parent company to have greater involvement in the affairs of the subsidiary so that the subsidiary abides by good practice and produces quality goods; liability may spur a parent to establish quality control procedures for its subsidiaries and follow up on due compliance. Conversely, such increased liability may breed a "dirty gumboot paradox", whereby, because the threshold for liability appears from JHI to be low, a parent may be discouraged from becoming involved with its subsidiary's affairs out of a concern it will be held liable if it has any knowledge of its subsidiary's operations - and is more likely to be liable the more it is involved.

\section{Commercial consequences}

Admittedly, the position as it stood previously has promoted some economic injustice which may be resolved or at least improved by virtue of the JHI decision. The concern about limited liability from an economic perspective is that, because shareholders enjoy all the benefits from the company's success, yet do not suffer the full costs of failure, a sort of moral hazard may develop whereby shareholders are able to externalise the risk of their activities. ${ }^{128}$ One of the potentially beneficial outcomes of this case is therefore the removal of an "insurance policy" whereby involuntary creditors and society in general pay for the costs of protecting businesses that risk creating economic losses.

However, the case also has the possibility to discourage the use of the corporate form for significant societal advantages, particularly in relation to the economy. This case demonstrates the willingness of a court, even in opposition to established tort doctrine and existing statutory remedies, to invade a parent company or group structure's assets. A parent company cognisant of such increased liability as $J H I$ portends may thus become dissuaded from instigating or allowing diversification and innovation and disengage from socially and economically useful but potentially risky activities. This would be on account of a judgement that since the potential cost of doing so may be much higher now, either in taking precautions against liability or in incurring a judgment debt, it is no longer worthwhile to undertake such activities.

128 Goddard, above n 21, at 15 . 
This is particularly so under the categories of liability established in $J H I$ as opposed to the more limited circumstances of potential liability in the cases cited dealing with personal injury. As noted, liability for economic loss opens a parent company to indeterminate liability in a way which the cases imposing liability for the health and safety of employees do not, meaning the categories and scope of liability under $J H I$ is much greater. The Court failed to make reference to these potential consequences of such expanded liability.

\section{LOOKING AHEAD}

It may be good public policy to hold a parent company liable for such loss as arose in JHI. However, the Court was wrong to introduce categories for potential parent company liability derived from rules from overseas cases dealing with entirely different sets of facts and policy considerations. The Court also failed to identify the departure from the present law this represented. Moreover, such a departure should arguably not have come from the courts, which have a limited ability to deal with complex issues like those which arose in JHI. A court has only so many resources available to it, particularly in time and staffing, and only so much ability to develop the law coherently since it must adjudicate on issues as they come before it. Commenting on the topic of liability in negligence for pure economic loss attributable to defects in buildings, Feldthusen and Brown have asserted that: ${ }^{129}$

The common law has proved incapable of dealing consistently with the policy issues involved ... Clearly the legislature is in a better position to commission such research from scratch and to bring a range of

legal options to bear on the subject ...

Indeed, the legislature enjoys the ability to proactively and carefully craft coherent, clear and accessible law, and it has the democratic mandate to do so. It is particularly appropriate for the legislature to make necessary amendments to the law in the light of existing, if clearly insufficient, statutory regimes for recovery: while it seems the claimants in the present case may have recovered against the parent companies under the FTA, the issues with liability under the CGA and the Companies Act were highlighted earlier. It is preferable to allow the legislature to amend existing statutory schemes rather than attempt to shape the common law in a theoretically problematic way.

The best option for ensuring parent company liability exists in the principle of enterprise liability. Essentially, this involves "treating all companies in a group as a single enterprise and holding the single enterprise responsible for harm caused by any individual company within the group". ${ }^{130}$ Indeed, the Court in JHI viewed the wider James Hardie group as a single entity. ${ }^{131}$ The approach

129 Bruce Feldthusen and Craig Brown "Pure Economic Loss: Who Should Pay, When and How?" (paper presented to Negligence after Murphy v Brentwood DC Conference, University of Auckland, 7 March 1991) at $47-48$.

130 Petrin and Choudhury, above n 1, at 785.

$131 \mathrm{JHI}$, above n 3, at [82] and [88]. 
removes concerns about making a parent company liable for a separate subsidiary company after the fact of liability incurred because the group carries on business understanding such potential liability. ${ }^{132}$ Thus, group corporations are not permitted to shift potentially risky or harmful activities to underfunded subsidiaries, but are forced to assess and address the risk holistically as a group. ${ }^{133}$ Meredith Dearborn notes that limited liability was never intended to address involuntary tort creditors or decentralised corporate groups and accordingly proposes a two-pronged approach for enterprise liability whereby an "enterprise" is identified on the basis of economic, as opposed to behavioural, control, and then held liable as a single group for mass torts. ${ }^{134}$ While a full exploration cannot be undertaken here, what this might look like in New Zealand is legislative amendment to the Companies Act (which already includes a similar regime in s 271) or CGA to impose wide liability on an economically-aligned corporate group which enters defective products into the stream of commerce.

\section{CONCLUSION}

In $J H I$ the Court of Appeal was faced with the difficult task of ensuring the ability for deserving claimants to be compensated for their loss in a legal setting with insufficient statutory recovery, deeprooted fundamental principles of company law and a confused jurisprudential history and outlook relating to the type of harm they suffered. However, in its search for potential categories of liability the Court inappropriately relied on overseas authorities involving distinct facts and fundamentally different underlying policy concerns. In failing to acknowledge these differences, the Court extended tort liability for economic loss to parent companies far beyond what courts in other jurisdictions have held, with potentially significant effects. A better route of liability in relation to companies within a corporate group which enters defective products into the stream of commerce exists in the principle of enterprise liability, but such a course of action is a matter best left for the legislature to implement, not the courts.

132 Petrin and Choudhury, above n 1 , at 785 .

133 Surya Deva Briefing Paper for Consultation: Parent Company Liability (ESCR-Net Treaty Initiative) at 3.

134 Meredith Dearborn "Enterprise Liability: Reviewing and Revitalizing Liability for Corporate Groups" (2009) 97 CLR 195 at 202-203 and 252-256. 
